\title{
Ионный состав природных вод притоков реки Дон в пределах Воронежской области
}

\author{
Чувычкин А.Л. ${ }^{1,2}$, Девятова Т.А. ${ }^{1}$, Яблонских Л.А. ${ }^{1}$ \\ ${ }^{l}$ ФГБУ ВО «Воронежский государственный университет», Воронеж \\ ${ }^{2}$ Филиал ЦЛАТИ по Воронежской области , Воронеж
}

Поступила в редакцию 25.01.2018 г.

DOI: https://doi.org/10.17308/sorpchrom.2018.18/548

Гидрохимическими исследованиями выявлены особенности ионного состава природных вод правобережных и левобережных притоков реки Дон в пределах Воронежской области. Дан анализ химического состава воды наиболее крупных притоков реки Дон, дренирующих Окско-Донскую равнину, Среднерусскую и Калачскую возвышенности. Показано преобладание природных факторов в формировании изменений содержания главных ионов в воде. По соотношению их концентрации определен тип химического состава воды рек.

Ключевые слова: поверхностные воды, реки Воронежской области, гидрохимические показатели, ионный состав, атомно-абсорбционный метод анализа, тяжелые металлы.

\section{Chemical composition of surface waters of the tributaries of the Don River within the Voronezh Region}

\author{
Chuvychkin A.L. ${ }^{1,2}$, Devyatova T.A. ${ }^{1}$, Yablonskikh L.A. ${ }^{1}$ \\ ${ }^{I}$ Voronezh State University, Voronezh \\ ${ }^{2}$ ChlATI branch in Voronezh region, Voronezh
}

In 2012-2016 years the study of the chemical composition of water and its change under the influence of wide range of factors was carrying out at stationary monitoring stations, which are located in the lower reaches of all investigated rivers. Standard methods, which are included in the State register of methods of quantitative chemical analysis of waters, were used.

Dissolved forms and the amount of forms of the metals copper, zinc, manganese and nickel were determined by PND F 14.1:2:4.214-06 " The method of determination of content by weight of iron, cadmium, cobalt, manganese, nickel, copper, zinc, chromium and lead in drinking, surface and waste water, by flame atomic absorption spectrometry". The SPEKTR 5-4 device was used. This analysis method is one of the most reliable. Also it has a good reproducibility of the results and capable to find even weak concentrations of substances in surface waters. From 2012 to 2016 the quarterly survey samples were carrying out in seven rightBank tributaries of the Don. It revealed that the amount of forms of copper more than dissolved forms on the average by 20 percent, and manganese by 25 percent.

These data demonstrate that copper and manganese are good absorbed on suspended substance or pass in colloidal form. These correlation of dissolved forms to the amount of forms holds only for body of water with low anthropogenic impact, fluctuation of suspended solids from $5 \mathrm{mg} / \mathrm{dm}^{3}$ to $7 \mathrm{mg} / \mathrm{dm}^{3}$, and pH from 6.5 to 8.5 . In general, the values of heavy metals, which were identified in the research, are conformed to the data of the state monitoring. For more informative data in environmental monitoring the determination of the dissolved form and the amount of forms of the metals copper, zinc, manganese, and nickel should be continued.

Keywords: surface waters, rivers of the Voronezh region, hydrochemical indicators, ion composition, atomic absorption method of analysis, heavy metals. 


\section{Введение}

Правобережные и левобережные притоки реки Дон в пределах Воронежской области несут богатую информацию о своем гидрохимическом состоянии, характерном для большинства средних и малых рек Центрального Черноземного региона (ЦЧР). Гидрохимический режим этих водотоков в целом оказывает существенное влияние на качество поверхностных вод реки Дон $[1,2]$. В связи с этим целью работы являлось получение и анализ разносторонней информации по ионному составу природной воды речных водотоков Воронежской области. Объектами наших исследований послужили реки Ведуга, Девица, Тихая Сосна, Черная Калитва, Богучарка, Воронеж, Икорец, Битюг, Осередь, Толучеевка. Указанные реки относятся к категории малых и средних рек, имеют полностью открытое русло, приуроченное в основном к территории Воронежской области, расположенной в пределах двух природных зон: лесостепной и степной. Питание рек смешанное, где главная роль принадлежит снеговому питанию с весенним половодьем.

Долины правобережных притоков Дона (Большая Верейка, Ведуга, Девица) врезаны в породы девонской геологической системы (известняки, глины, мергели). Прокладывая свой путь в плотных девонских известняках, реки выработали неширокие, но глубокие долины с переменной асимметрией склонов. Долины рек мелового юга Среднерусской возвышенности (Потудань, Тихая Сосна, Черная Калитва, Богучарка) глубоко врезаны в толщу осадочного чехла Воронежской антеклизы и меловую геологическую систему (мел, мергель). Мело-мергельные породы представлены писчим мелом туронского и мергелем сантонского ярусов (мощность 200-250м). Речные долины мелового юга шире и глубже, чем выработанные их аналоги в известняках северной части Среднерусской возвышенности, что объясняется своеобразием литологии меловых пород, и прежде всего способностью легко разрушаться под воздействием воды [2,3]. Долины левобережных притоков Дона (Воронеж, Икорец, Битюг, Савала, Елань, Хопер) дренируют Окско-Донскую равнину в северной, центральной и восточной частях Воронежской области, а на ее юге такие реки, как Осередь, Толучеевка - Калачскую возвышенность. Водосборы рек Окско-Донской равнины сложены мощными, рыхлыми породами четвертичного периода. Основная ландшафтообразующая роль на территории Калачской возвышенности принадлежит мелу и мергелям [4].

\section{Эксперимент}

Отбор проб воды для изучения химического состава и его изменения под влиянием разнообразных факторов проводили в 2012-2016 гг. на мониторинговых стационарных участках, находящихся в нижнем течении основных притоков Дона. Лабораторные исследования осуществлялись с помощью атомно-абсорбционного метода, а также стандартных методик внесенных в Государственный реестр методов количественного химического анализа вод.

Растворенные формы и сумму форм металлов меди, цинка, марганца и никеля определяли по ПНД Ф 14.1:2:4.214-06 «Методика определения массовых концентраций металлов в поверхностных водах методом пламенной атомно-абсорбционной спектрометрии» на приборе СПЕКТР 5-4. Другие ПНД Ф, которые использовались для определения гидрохимических показателей, а также их концентрации представлены в таблицах 1 и 2. 
Таблица 1 . Среднестатистические значения гидрохимических показателей правобережных притоков Дона за 2012-2016 гг.

\begin{tabular}{|c|c|c|c|c|c|c|c|c|c|}
\hline \multicolumn{2}{|c|}{$\begin{array}{c}\text { Номер пробы } \\
\text { и место отбора проб }\end{array}$} & \multicolumn{8}{|c|}{$\begin{array}{c}\text { №1 - Вода из р. Большая Верейка, Рамонский район, (устье) } \\
\text { №2 - Вода из р. Ведуга, Семилукский район (устье) } \\
\text { №3 - Вода из р. Девица, Семилукский район (устье) } \\
\text { №4- Вода из р. Девица, Острогожский район (устье) } \\
\text { №5 - Вода из р. Тихая Сосна, Острогожский район (устье) } \\
\text { №6 - Вода из р. Черная Калитва, Ольховатский район (устье) } \\
\text { №7- Вода из р. Богучарка у с. Писаревка, Богучарский район (устье) }\end{array}$} \\
\hline $\begin{array}{l}\text { № } \\
\text { п/п }\end{array}$ & $\begin{array}{c}\text { Определяемый } \\
\text { показатель, еди- } \\
\text { ница измерения }\end{array}$ & №1 & №2 & №3 & №4 & №5 & №6 & №7 & $\begin{array}{c}\text { Методики из- } \\
\text { мерений }\end{array}$ \\
\hline 1 & $\begin{array}{l}\text { Водородный по- } \\
\text { казатель, ед. рН }\end{array}$ & 7.3 & 7.6 & 7.8 & 7.5 & 7.4 & 7.6 & 7.9 & $\begin{array}{c}\text { ПНД } \\
\Phi 14.1: 2: 3: 4.121 \\
-97 \\
\end{array}$ \\
\hline 2 & $\begin{array}{l}\text { Взвешенные ве- } \\
\text { щества, мг/дм³ }\end{array}$ & 6.5 & 6.8 & 7.0 & 6.3 & 4.8 & 5.9 & 5.6 & $\begin{array}{c}\text { ПНД Ф } \\
\text { 14.1:2.110-97 }\end{array}$ \\
\hline 3 & $\begin{array}{c}\text { Сухой остаток, } \\
\text { мг/дм }{ }^{3} \\
\end{array}$ & 325 & 341 & 359 & 384 & 811 & 1114 & 1472 & $\begin{array}{c}\text { ПНД Ф } \\
\text { 14.1:2.114-97 } \\
\end{array}$ \\
\hline 4 & $\begin{array}{c}\text { Сульфат-ион, } \\
\text { мг/дм }{ }^{3} \\
\end{array}$ & 30.4 & 34.0 & 35.5 & 65.2 & 142 & 214 & 256 & $\begin{array}{c}\text { ПНД Ф } \\
14.1: 2.159-2000 \\
\end{array}$ \\
\hline 5 & $\begin{array}{c}\text { Хлорид-ион, } \\
\text { мг/дм }{ }^{3} \\
\end{array}$ & 20.2 & 22.3 & 25.2 & 45.6 & 58.1 & 126 & 389 & $\begin{array}{c}\text { ПНД } Ф \\
\text { 14.1:2.96-97 } \\
\end{array}$ \\
\hline 6 & ХПК, мг/дм ${ }^{3}$ & 23.9 & 24.8 & 25.7 & 22.9 & 23.4 & 26.4 & 25.2 & $\begin{array}{c}\text { ПНД Ф } \\
14.1: 2: 4.190-03 \\
\end{array}$ \\
\hline 7 & БПК ${ }_{5}$, мГ $\mathrm{O}_{2} /$ дм $^{3}$ & 2.17 & 2.24 & 2.47 & 2.13 & 2.26 & 2.51 & 2.74 & $\begin{array}{c}\text { ПНД Ф } \\
14.1: 2: 3: 4.123- \\
97 \\
\end{array}$ \\
\hline 8 & $\begin{array}{c}\text { Аммоний - ион, } \\
\text { мг/дм }{ }^{3}\end{array}$ & 0.24 & 0.26 & 0.51 & 0.36 & 0.31 & 0.34 & 0.24 & $\begin{array}{c}\text { ПНД Ф } \\
14.1: 2: 4.262-10 \\
\end{array}$ \\
\hline 9 & $\begin{array}{c}\text { Нитрит-ион, } \\
\text { мг/дм }\end{array}$ & 0.025 & 0.026 & 0.033 & 0.028 & 0.031 & 0.040 & 0.030 & $\begin{array}{c}\text { ПНД Ф } \\
14.1: 2: 4.3-95 \\
\end{array}$ \\
\hline 10 & $\begin{array}{c}\text { Нитрат-ион, } \\
\text { мг/дм }\end{array}$ & 2.06 & 2.02 & 2.39 & 1.69 & 1.26 & 2.97 & 1.56 & $\begin{array}{c}\text { ПНД Ф } \\
14.1: 2: 4.4-95 \\
\end{array}$ \\
\hline 11 & $\begin{array}{c}\text { Фосфат-ион, } \\
\text { мг/дм }{ }^{3} \\
\end{array}$ & 0.28 & 0.24 & 0.61 & 0.27 & 0.46 & 0.39 & 0.41 & $\begin{array}{c}\text { ПНД Ф } \\
14.1: 2: 4.112-97 \\
\end{array}$ \\
\hline 12 & $\begin{array}{c}\text { Железо общее, } \\
\text { мг/дм }{ }^{3} \\
\end{array}$ & 0.07 & 0.07 & 0.07 & 0.05 & 0.06 & 0.07 & 0.07 & $\begin{array}{c}\text { ПНД } \Phi \\
14.1: 2.2-95 \\
\end{array}$ \\
\hline 13 & $\begin{array}{l}\text { Нефтепродукты, } \\
\text { мг/дм }\end{array}$ & 0.041 & 0.042 & 0.046 & 0.042 & 0.044 & 0.042 & 0.043 & $\begin{array}{c}\text { ПНДФ } \\
14.1: 2: 4.168-00\end{array}$ \\
\hline 14 & $\begin{array}{c}\text { Жесткость общая, } \\
{ }^{0} \text { Ж } \\
(\text { мг-экв/ дм³) }\end{array}$ & 6.5 & 6.9 & 7.0 & 7.9 & 9.0 & 8.7 & 10.3 & $\begin{array}{c}\text { ПНД Ф } \\
\text { 14.1:2.98-97 } \\
\end{array}$ \\
\hline 15 & Кальций, мг/дм³ & 83.0 & 90.3 & 94.6 & 96.3 & 107 & 212 & 322 & $\begin{array}{c}\text { ПНД Ф } \\
\text { 14.1:2.95-97 } \\
\end{array}$ \\
\hline 16 & Магний, мг/дм ${ }^{3}$ & 17.2 & 22.1 & 26.2 & 28.7 & 43.8 & 45.6 & 52.2 & РЭ «Спектр-5» \\
\hline 17 & Натрий, мг/дм³ & 14.7 & 15.8 & 15.9 & 19.9 & 25.4 & 28.2 & 66.8 & РЭ «Спектр-5» \\
\hline 18 & $\begin{array}{c}\text { Гидрокарбонат- } \\
\text { ион,мг/дм }\end{array}$ & 343 & 384 & 404 & 444 & 602 & 724 & 925 & $\begin{array}{c}\text { ПНДФ 14.2.99- } \\
97 \\
\end{array}$ \\
\hline 19 & Медь (р.ф), мг/дм & 0.0014 & 0.0014 & 0.0018 & 0.0016 & 0.0018 & 0.0018 & 0.0018 & $\begin{array}{c}\text { ПНД Ф } \\
14.1: 2: 4.214-06 \\
\end{array}$ \\
\hline 20 & Цинк (р.ф), мг/дм & 0.0058 & 0.0082 & 0.0084 & 0.0076 & 0.0062 & 0.0073 & 0.0062 & $\begin{array}{c}\text { ПНД Ф } \\
14.1: 2: 4.214-06 \\
\end{array}$ \\
\hline 21 & $\begin{array}{c}\text { Никель (р.ф), } \\
\text { мг/дм }\end{array}$ & $<0.005$ & $<0.005$ & $<0.005$ & $<0.005$ & $<0.005$ & $<0.005$ & $<0.005$ & $\begin{array}{c}\text { ПНД Ф } \\
14.1: 2: 4.214-06 \\
\end{array}$ \\
\hline 22 & $\begin{array}{c}\text { Марганец(р.ф), } \\
\text { мг/дм }\end{array}$ & 0.0085 & 0.0086 & 0.011 & 0.0091 & 0.012 & 0.013 & 0.014 & $\begin{array}{c}\text { ПНД Ф } \\
14.1: 2: 4.214-06\end{array}$ \\
\hline
\end{tabular}


Таблица 2 . Среднестатистические значения гидрохимических показателей левобережных притоков Дона за 2012-2016 гг.

\begin{tabular}{|c|c|c|c|c|c|c|c|}
\hline \multirow{2}{*}{\multicolumn{2}{|c|}{$\begin{array}{c}\text { Номер пробы и место отбо- } \\
\text { ра проб }\end{array}$}} & \multicolumn{6}{|c|}{$\begin{array}{c}\text { №1 - Вода из р. Воронеж, (устье) } \\
\text { №2 - Вода из р. Икорец, Лискинский район (устье) } \\
\text { №3 - Вода из р. Битюг, Бобровский район (устье) } \\
\text { №4 - Вода из р. Осередь, Павловский район (устье) } \\
\text { №5 - Вода из р. Толучеевка, Петропавловский район (устье) }\end{array}$} \\
\hline & & \multicolumn{3}{|c|}{$\begin{array}{c}\text { Окско-Донская равни- } \\
\text { на } \\
\end{array}$} & \multicolumn{3}{|c|}{ Калачская возвышенность } \\
\hline $\begin{array}{l}\text { № } \\
\Pi / \Pi\end{array}$ & $\begin{array}{c}\text { Определяемый показа- } \\
\text { тель, единица измере- } \\
\text { ния } \\
\end{array}$ & №1 & №2 & № 3 & №4 & №5 & Методики измерений \\
\hline 1 & $\begin{array}{c}\text { Водородный показа- } \\
\text { тель, ед. } \mathrm{pH}\end{array}$ & 7.8 & 7.6 & 7.9 & 7.7 & 8.1 & ПНД Ф14.1:2:3:4.121-97 \\
\hline 2 & $\begin{array}{c}\text { Взвешенные вещества, } \\
\text { мг/дм }{ }^{3}\end{array}$ & 5.9 & 5.4 & 7.0 & 6.8 & 7.4 & ПНД Ф 14.1:2.110-97 \\
\hline 3 & Сухой остаток, мг/дм ${ }^{3}$ & 459 & 583 & 609 & 755 & 1132 & ПНД Ф 14.1:2.114-97 \\
\hline 4 & Сульфат-ион, мг/дм ${ }^{3}$ & 56.8 & 84.8 & 99.8 & 124 & 283 & ПНД Ф 14.1:2.159-2000 \\
\hline 5 & Хлорид-ион, мг/дм ${ }^{3}$ & 30.0 & 42.9 & 51.4 & 110 & 195 & ПНД Ф 14.1:2.96-97 \\
\hline 6 & ХПК, мг/дм ${ }^{3}$ & 25.5 & 20.8 & 21.8 & 22.2 & 27.3 & ПНД Ф 14.1:2:4.190-03 \\
\hline 7 & БПК ${ }_{5}$, мг $\mathrm{O}_{2} /$ дм $^{3}$ & 2.48 & 2.12 & 2.10 & 2.18 & 2.66 & ПНД Ф 14.1:2:3:4.123-97 \\
\hline 8 & $\begin{array}{c}\text { Аммоний - ион, } \\
\text { мг/дм }{ }^{3} \\
\end{array}$ & 0.42 & 0.27 & 0.31 & 0.40 & 0.30 & ПНД Ф 14.1:2:4.262-10 \\
\hline 9 & Нитрит-ион, мг/дм ${ }^{3}$ & 0.023 & 0.021 & 0.023 & 0.026 & 0.022 & ПНД Ф 14.1:2:4.3-95 \\
\hline 10 & Нитрат-ион, мг/дм ${ }^{3}$ & 2.61 & 1.22 & 1.18 & 1.98 & 1.65 & ПНД Ф 14.1:2:4.4-95 \\
\hline 11 & Фосфат-ион, мг/дм ${ }^{3}$ & 0.88 & 0.53 & 0.56 & 0.61 & 0.28 & ПНД Ф 14.1:2:4.112-97 \\
\hline 12 & Железо общее, мг/дм ${ }^{3}$ & 0.06 & 0.06 & 0.06 & 0.07 & 0.10 & ПНД Ф 14.1:2.2-95 \\
\hline 13 & Нефтепродукты, мг/дм & 0.052 & 0.041 & 0.043 & 0.045 & 0.048 & ПНДФ 14.1:2:4.168-2000 \\
\hline 14 & $\begin{array}{c}\text { Жесткость общая, }{ }^{0} Ж \\
\left(\text { мг-экв/ дм }{ }^{3}\right) \\
\end{array}$ & 6.1 & 7.7 & 8.3 & 8.6 & 9.4 & ПНД Ф 14.1:2.98-97 \\
\hline 15 & Кальций, мг/дм ${ }^{3}$ & 68.7 & 110 & 116 & 122 & 215 & ПНД Ф 14.1:2.95-97 \\
\hline 16 & Магний, мг/дм ${ }^{3}$ & 24.0 & 29.9 & 37.6 & 35.4 & 44.3 & РЭ «Спектр-5» \\
\hline 17 & Натрий, мг/дм ${ }^{3}$ & 16.2 & 19.8 & 22.6 & 32.4 & 42.2 & РЭ «Спектр-5» \\
\hline 18 & $\begin{array}{c}\text { Гидрокарбонат - ион, } \\
\text { мг/дм }{ }^{3}\end{array}$ & 366 & 444 & 502 & 543 & 683 & ПНДФ 14.2.99-97 \\
\hline 19 & Медь, мг/дм ${ }^{3}$ & 0.0024 & 0.0013 & 0.0013 & 0.0015 & 0.0018 & ПНД Ф 14.1:2:4.214-06 \\
\hline 20 & Цинк, мг/дм ${ }^{3}$ & 0.0085 & 0.0075 & 0.0072 & 0.0077 & 0.0085 & ПНД Ф 14.1:2:4.214-06 \\
\hline 21 & Никель, мг/дм ${ }^{3}$ & $<0.005$ & $<0.005$ & $<0.005$ & $<0.005$ & $<0.005$ & ПНД Ф 14.1:2:4.214-06 \\
\hline 22 & Марганец, мг/дм ${ }^{3}$ & 0.014 & 0.0080 & 0.0074 & 0.012 & 0.011 & ПНД Ф 14.1:2:4.214-06 \\
\hline
\end{tabular}

Экспериментальные данные, по указанным выше водным объектам, позволившие дать анализ химического состава акватории рек за период с 2012 по 2016 год, были получены в филиале ЦЛАТИ по Воронежской области.

\section{Обсуждение результатов}

На формирование химического состава поверхностных вод оказывают влияние климатические условия, геологическое строение (состав подстилающих и почвообразующих пород), почвенный и растительный покровы, другие факторы. Значительным изменениям подвергаются атмосферные осадки при инфильтрации через породы зоны аэрации, что приводит к увеличению минерализации воды и содержания в ней основных ионов. В дальнейшем, при движении воды в водоносном горизонте и попадании ее в поверхностные водотоки, данные процессы продолжаются. Формирование химического состава вод при этом в большой степени зависит от 
времени их контакта с почвами и породами [5].

Установлены следующие основные тенденции изменения гидрохимических показателей в изучаемых поверхностных водных объектах (табл.1,2).

По гидрохимической классификации О.А. Алекина [1], воды правобережных притоков реки Дон, таких как Большая Верейка, Ведуга и Девица относятся к типу гидрокарбонатно-кальциевых с минерализацией от 325 до 384 мг/дм ${ }^{3}$. В водах рек Тихая Сосна, Черная Калитва и Богучарка минерализация возрастает от 811 до 1472 мг/дм ${ }^{3}$, а химический тип воды становится гидрокарбонатно-сульфатным кальциево-магниевым (Тихая Сосна и Черная Калитва) и смешанного ионного состава у вод реки Богучарка (гидрокарбонатно-хлоридно-сульфатный кальциево-натриевый). Значения рН варьируют от 7.3 до 7.9.

По степени общей жесткости, исследуемые воды классифицируются как средне-жесткие (6.5-7.9 мг-экв/дм $\left.{ }^{3}\right)$ и жесткие (9.0-10.3 мг-экв/дм $\left.{ }^{3}\right)$. Обычно преобладает жесткость, обусловленная ионами кальция. Жесткость воды зависит от наличия в нем растворенных солей кальция и магния, количество которых возрастает в водах рек мелового юга Среднерусской возвышенности (реки Черная Калитва и Богучарка). Концентрация кальция и магния изменялась в пределах 83-322 и 17-52 мг/дм ${ }^{3}$ соответственно. Величина отношения концентраций ионов кальция и магния $\left(\mathrm{Ca}^{2+} / \mathrm{Mg}^{2+}\right)$ в водах рек Большая Верейка, Ведуга, Девица и Черная Калитва была равна 3.3-4.8. Река Богучарка, самый южный из исследуемых правобережных притоков реки Дон, имела соотношение 6/1. Это связано с вымыванием из геологических пород большого количества гидрокарбоната кальция, который на территории мелового юга Среднерусской возвышенности достигает 80-90\%. Нетипичным правобережным притоком по соотношению кальция и магния являлась река Тихая Сосна, где указанное соотношение было $2 / 1$. Отношение $\mathrm{Ca}^{2+} / \mathrm{Na}^{+}$находилось в пределах 4.3-7.5, где минимальный уровень приходился также на Тихую Сосну. По сравнению с реками известнякового севера Среднерусской возвышенности в ионной композиции природных вод ее мелового юга, возрастает: 1 . доля сульфат-иона в реке Тихая Сосна в 2-4 раза, в реках Черная Калитва и Богучарка - в 6-7 раз; 2. доля хлорид-иона в водах Тихой Сосны - в 2-3 раза, Черной Калитвы-5 раз и Богучарки 19 раз.

УКИЗВ (удельный комбинаторный индекс загрязненности воды) в исследуемых правобережных притоках Дона, за все время наблюдения, находился в пределах 2.1-2.9. Соответственно ему класс качества воды относится к третьему, разряд «а» (загрязненная). Третий класс разряд «а» качества воды сложился из-за превышения ПДК (предельно допустимой концентрации) для воды водоемов рыбохозяйственного значения по таким показателям, как хлорид-ион, сульфат-ион, растворенные формы меди, органическое вещество по БПК. В ряде проб отмечается повышенное содержание растворенных форм марганца.

Природные воды левобережных притоков реки Дон, приуроченные к ОкскоДонской равнине (реки Воронеж, Икорец, Битюг и др.), относятся к гидрокарбонатно-кальциевому типу с минерализацией в пределах 459-609 мг/дм ${ }^{3}$. Величина $\mathrm{pH}$ у них варьировала от 7.6 до 7.9 (табл. 2). Кроме того, здесь встречаются воды рек смешанных или промежуточных типов, а среди катионов выделяются группы кальциевых, магниевых или натриевых вод.

По степени общей жесткости, воды рек Окско-Донской равнины классифицируются как средне-жесткие (7.8-7.9 мг-экв/дм³ $)$. Содержание ионов кальция варьировало от 68.7 мг/дм ${ }^{3}$ в реке Воронеж до 110 и 116 мг/дм ${ }^{3}$ в реках Икорец и Битюг соответственно. Концентрация ионов магния изменялась от 24.0 мг/дм³ в реке Воронеж до 29.9 и 37.6 мг/дм³ в реках Икорец и Битюг. В течение всего периода исследований 
величины отношений $\mathrm{Ca}^{2+} / \mathrm{Mg}^{2+}$ и $\mathrm{Ca}^{2+} / \mathrm{Na}^{+}$в водах рек Окско-Донской равнины составляли 2.9-3.7 и 4.2-5.5 соответственно. В отличие от химического состава поверхностных вод рек Среднерусской возвышенности, в ионной композиции рек ОкскоДонской равнины выше содержание сульфат- и хлорид- ионов по отношению к рекам известнякового севера и ниже - по этим же ионам, по отношению к рекам мелового юга и Калачской возвышенности.

УКИЗВ в исследуемых реках Окско-Донской равнины за все время наблюдения находился в пределах 2.4-2.8. Соответственно ему класс качества воды относится к третьему, разряд «а» (загрязненная). Третий класс разряд «а» качества воды сложился из-за превышения ПДК по таким показателям, как растворенные формы меди, марганца, органическое вещество по БПК 5 .

Природные воды рек Калачской возвышенности (Осередь и Толучеевка), как и воды рек мелового юга Среднерусской возвышенности соответствует гидрокарбонатно-сульфатно-хлоридному кальциево-натриевому типу. По степени общей жесткости они классифицируются как средне-жесткие (7.7-8.1 мг-экв/дм ${ }^{3}$ ). Содержание ионов кальция варьировало от 122 мг/дм ${ }^{3}$ в реке Осередь до 215 мг/дм ${ }^{3}$ в реке Толучеевка. Количество ионов магния и натрия менялось аналогично ионам кальция от 35.4 до 44.3 мг/дм ${ }^{3}$ и от 32.4 до 42.2 мг/дм ${ }^{3}$ соответственно. Таким образом, концентрация ионов кальция была в 3.5-5.0 раз выше концентрации ионов магния и в 3.85.1 раза выше концентрации ионов натрия. Значения $\mathrm{pH}$ составляли 7.7-8.1.

УКИЗВ в исследуемых реках Калачской возвышенности был равен 2.5 в реке Осередь и 2.7 в реке Толучеевка. Класс качества воды относится к третьему, разряд «а» (загрязненная). Третий класс разряд «а» качества воды сложился из-за превышения ПДК по таким показателям, как сульфат-ион, растворенные формы меди, марганца, органическое вещество по БПК.

При определении содержания тяжелых металлов в поверхностных водах рек выявлены следующие тенденции. Концентрации растворенных форм меди и марганца, как и общая минерализация, увеличивались в водах реках мелового юга.

Медь в поверхностных и подземных водах содержится в ионной форме и в виде комплексных соединений с органическими и неорганическими веществами. Средние значения растворенных форм меди за период наблюдения в правобережных притоках составили 0.0014-0.0018 мг/дм ${ }^{3}$ или 1.4-1.8 ПДК.

В левобережных притоках эти показатели соответственно равны 0.0013$0.0024 \mathrm{мг} /$ дм $^{3}$ или 1.3-2.4 ПДК. Максимальные концентрации растворенных форм меди $\left(0.0024\right.$ мг/дм $\left.{ }^{3}\right)$ отмечены в поверхностных водах реки Воронеж, которая испытывает повышенную антропогенную нагрузку.

Концентрации растворенных форм марганца в поверхностных водах правобережных притоков были выше предельно допустимых в реках Девица, Тихая Сосна, Черная Калитва и Богучарка и были равны 0.011-0.014 мг/дм³ (1.1-1.4 ПДК). В поверхностные значительные количества марганца поступают в процессе разложения водных, животных и растительных организмов, особенно, синезеленых, диатомовых водорослей, а также высших водных растений. Так при движении с севера на юг области увеличивается солнечная инсоляция, что влечет прирост биомассы водных растений, которые и увеличивают концентрации марганца в воде. Концентрации цинка были стабильны у всех притоков Дона и изменялись в пределах погрешности измерений от 0.0058 до 0.010 мг/дм³

Растворенные формы никеля, которые представляют собой главным образом комплексные ионы в исследуемых водоемах находились ниже предела обнаружения (менее 0.005 мг/дм ${ }^{3}$ ). В связи с началом разносторонних исследовательских работ на медно-никелевых месторождениях Воронежской области, необходимо также уделять 
этому металлу повышенное внимание. Также в ходе исследования поверхностных вод были выявлены закономерности по соотношению сумм форм металлов меди и марганца к их растворенным формам.

При ежеквартальном исследовании проб воды притоков реки Дон в период с 2012 по 2016 год выявлено, что сумма форм меди больше растворенных форм в среднем на 20 процентов (рис.1), а марганца на 25 процентов (рис.2).

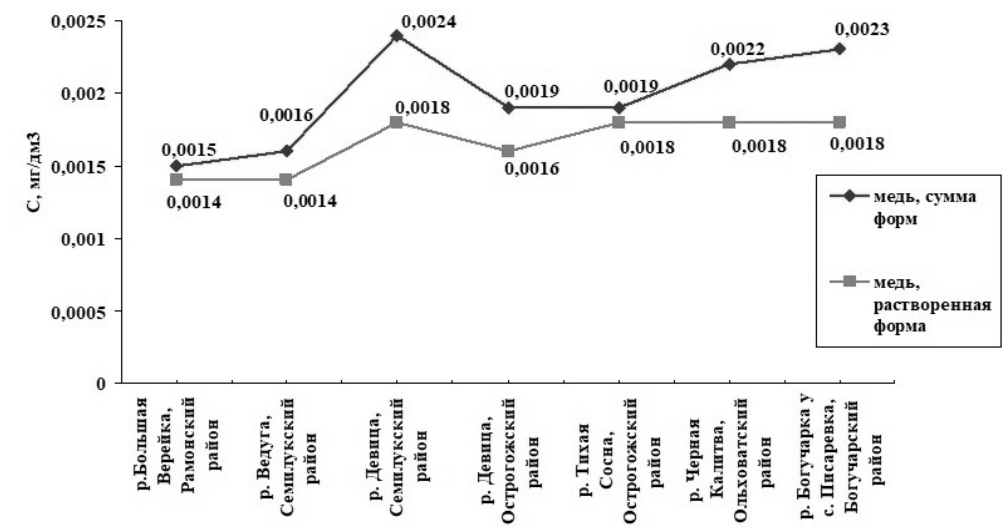

Рис. 1. Средние концентрации растворенных форм и суммы форм меди в исследуемых поверхностных водах за 2012-2016 гг.

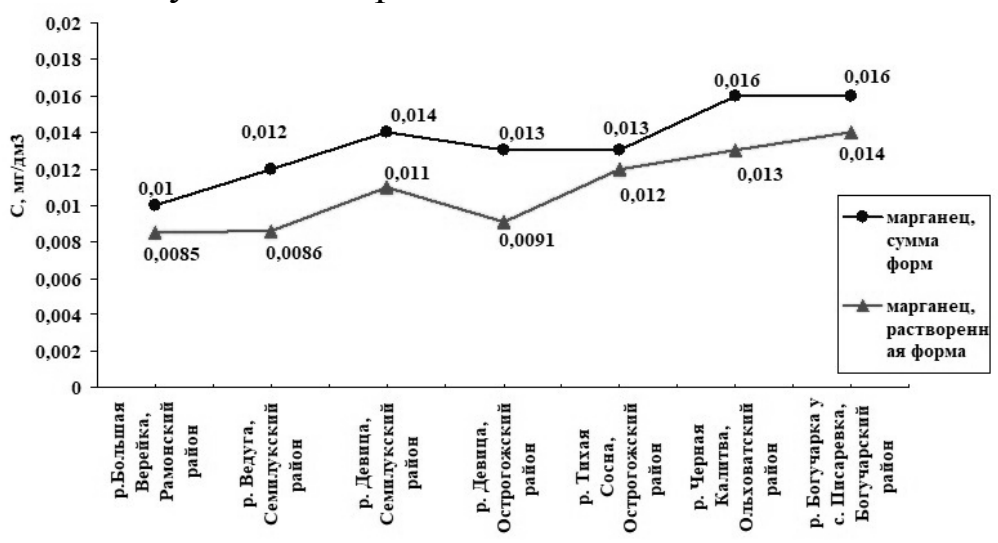

Рис. 2. Средние концентрации растворенных форм и суммы форм марганцав исследуемых поверхностных водах за 2012-2016 гг.

Данные значения показывают, что медь и марганец хорошо абсорбируются на взвешенных частицах или переходят в коллоидную форму. Стоит отметить, что данные соотношения растворенных форм к сумме форм верны только для водоемов с низкой антропогенной нагрузкой, колебанием взвешенных веществ от 5 до 7 мг/дм ${ }^{3}$ и величине $\mathrm{pH}$ от 6.5 до 8.5. Как один из примеров отклонения, на рис. 1-2, река Девица Семилукского района, которая испытывает повышенное антропогенное воздействие. Одним из источников поступления недостаточно очищенных сточных вод являются очистные сооружения ООО «Теплоснаб» [6]. Ниже сброса сточных вод в реку Девица отмечены превышения органических веществ и тяжелых металлов в десятки раз.

Также было выявлено, что концентрация марганца в поверхностных водах подвержена сезонным колебаниям. Максимальные сезонные значения во всех исследуемых водоемах приходились на сентябрь-ноябрь (3-4 квартал).

Выявлено, что цинк в поверхностных водах преобладал в растворенной форме - разница между растворенной формой и суммой форм была незначительной и в пределах погрешности измерений. 
Притоки, сливаясь с рекой Дон, неизбежно влияют на химический состав главной водной артерии. Стоит отметить, что наибольшее влияние на гидрохимический состав Дона оказывают реки мелового юга Среднерусской возвышенности, которые несут повышенное содержание растворенных солей (от 811 мг/дм ${ }^{3}$ в реке Тихая Сосна до 1472 мг/дм³ в реке Богучарка). Если в створе в Рамонском районе минерализация реки Дон за период наблюдений колебалась в пределах от 342 до 449 мг/дм ${ }^{3}$, то в Богучарском районе значения колебались от 531 до 712 мг/дм³ ${ }^{3}$ Основной вклад в увеличение минерализации внесли такие показатели, как гидрокарбонат-ион, хлорид-ион и сульфат-ион. Значение $\mathrm{pH}$ варьирует от 7.4 до 8.0, а общая жесткость от 6 до 9 мг-экв/дм ${ }^{3}$. Содержание растворенных форм тяжелых металлов и неорганических соединений азота и фосфора было стабильным на всем протяжении реки Дон и изменялись в пределах погрешности.

\section{Заключение}

Результаты проведенных исследований показывают, что реки Воронежской области характеризуются значительной гетерогенностью ионного состава водной среды, формируемой комплексным воздействием природных и антропогенных факторов. Принадлежность речных бассейнов рек к лесостепной и степной зонам Среднерусской и Окско-Донской провинциям, а также многочисленным (10) экологогеографическим районам, находит свое отражение в гидрохимии поверхностных вод. Гидрохимический режим реки Дон и его средних притоков является типичным для лесостепной и степной зон: им присуща устойчивость химического состава по главным ионам, слабощелочной характер водной среды, умеренная жесткость, низкая концентрация микрокомпонентов. Воды малых рек по своему ионному составу индивидуальны и несут черты своего эколого-географического района, который они дренируют. Установлены основные тенденции изменения концентрации ионов в устьях исследуемых рек: средняя многолетняя минерализация воды рек ОкскоДонской равнины (левобережные притоки Дона) составляла 459-609 мг/дм³, рек Среднерусской возвышенности 325-334 мг/дм (правобережные притоки известнякового севера), 811-1472 мг/дм ${ }^{3}$ (правобережные притоки мелового юга) и 7551132 мг/дм ${ }^{3}$ у рек южного ее продолжения (Калачской возвышенности). Вклад источников организованного и диффузного сброса сточных вод приводил к увеличению значений этого показателя и он имел локальный характер. При изменении минерализации, соотношение между ионами сохранялось: $\mathrm{HCO}_{3}{ }^{-}>\mathrm{SO}_{4}{ }^{2-}>\mathrm{Cl}^{-}>\mathrm{Ca}^{2+}>$ $\mathrm{Mg}^{2+}>\mathrm{Na}^{+}$.

Расположение бассейнов некоторых рек в степной части Воронежской области, а именно в зоне недостаточного увлажнения, с непромывным водным режимом почв, особенно от легкорастворимых солей (сульфатов и хлоридов), приводит к снижению в ионном составе воды доли гидрокарбонатов, возрастанию доли более подвижных мигрантов-соединений натрия и хлора, а в целом, к повышению испарительной концентрации большой группы элементов и значений $\mathrm{pH}$.

Качество воды реки Дон периодически ухудшается в местах впадения отдельных ее притоков, а также после близко расположенных населенных пунктов по мере ее течения с севера на юг области за счет диффузного селитебного сельскохозяйственного или комплексного организованного и диффузного селитебнопромышленного сброса сточных вод.

Приведенный выше анализ ионного состава поверхностных вод притоков Дона, показывает необходимость учета природных характеристик водной среды, на фоне которых регистрируются изменения ее качества за счет антропогенных нагру-

Чувычкин и др. / Сорбционные и хроматографические процессы. 2018. Т. 18. № 3 
зок для оценки буферной емкости водных экосистем к поступлению опасных загрязняющих веществ.

\section{Список литературы}

1. Алекин О.А. Основы гидрохимии. Л. Гидрометеоиздат. 1970. 414 с.

2. Эколого-географический атлас-книга Воронежской области / Под ред. В.И. Федотова. Воронеж. Изд-во ВГУ. 2013. 514 с.

3. Долинно-речные ландшафты среднерусской лесостепи / Под ред. Ф.Н. Милькова, В.Б. Михно, К.А. Дроздова и др. Воронеж. Изд-во ВГУ. 1987. $256 \mathrm{c.}$

4. Курдов А.Г. Водные ресурсы Воронежской области: формирование, антропогенное

\section{References}

1. Alekhin O.A., Fundamentals of hydrochemistry, L., Gidrometeoizdat, 1970. 414 p.

2. Ecological-geographical atlas-book of the Voronezh Region, Ed. V.I. Fedotov. Voronezh: Publishing House of VSU, 2013. 514 p.

3 . Valley-river landscapes of the Central Russian forest-steppe, Ed. F.N. Milkov, V.B. Mikhno, K.A. Drozdov et al., Voronezh, Publishing House of VSU, 1987, $256 \mathrm{p}$.

4. Kurdov A.G., Water resources of the Voro-

Чувычкин Андрей Леонидович - аспирант кафедры экологии и земельных ресурсов Воронежского государственного университета, ассистент кафедры экологии и земельных ресурсов, ведущий инженер отдела аналитических исследований филиала ЦЛАТИ по Воронежской области, Воронеж

Девятова Татьяна Анатольевна - д.б.н., профессор, заведующая кафедрой экологии и земельных ресурсов Воронежского государственного университета, Воронеж

Яблонских Лидия Александровна - д.б.н., профессор кафедры экологии и земельных ресурсов Воронежского государственного университета, Воронеж воздействие, охрана и расчеты. Воронеж. Изд-во ВГУ. 1995. 255 с.

5. Смольянинов B.M. Подземные воды центрально-чернземного региона: условия их формирования, использовании: монография. Воронеж. Изд-во Воронежского государственного агроуниверситета. 2003. 250 с.

6. Чувычкин А.Л. // Вода: химия и экология. 2016. № 6. $\quad$ С. $3-8$ bftp://watchemec.ru/article/27984/

nezh region: formation, anthropogenic impact, protection and calculations, Voronezh, Publishing House of VSU, 1995, 255 p.

5. Smolyaninov V.M. Underground waters of the Central Black soil region: conditions for their formation, use: monograph, Voronezh, Publishing House of VSU, 2003, 250 p.

6. Chuvychkin A.L., J. Water: chemistry and ecology, 2016, No 6, pp. 3-8- bftp: //watchemec.ru/article/27984/

Chuvychkin Andrey L. - post-graduate student department of ecology and ground resources, VSU, Voronezh, E-mail: chuvychkin@yandex.ru

Devyatova Tatyana A. - professor of department of ecology and ground resources, grand Ph.D (biology),VSU, Voronezh

Yablonskikh Lidia A. - professor of department of ecology and ground resources, grand Ph.D (biology),VSU, Voronezh 